\title{
Is a Company's Access to Private Equity and Venture Capital Affected by Location or Management Diversity? Some Empirical Evidence from Austria
}

\author{
Sascha Sardadvar ${ }^{1}$ \\ ${ }^{1}$ WPZ Research Vienna, Austria \\ Correspondence: Sascha Sardadvar, WPZ Research, Mariahilfer Strasse 115/16, 1060 Vienna, Austria. E-mail: \\ sascha.sardadvar@wpz-research.com
}

Received: April 13, 2018

doi:10.5539/ijbm.v13n7p45

\begin{abstract}
Governments around the world are providing various forms of subsidies to promote private investments into young, innovative firms. Under these circumstances it becomes ever more important to identify possible imbalances of risk capital (i.e. private equity and/or venture capital) markets. The present study provides econometric analyses (propensity score matching and probit regressions) based on firm data with the estimations displaying some distortions. In particular, a location outside Vienna as well as its shares of female and foreign managers display negative impacts on a company's likelihood to be risk financed.
\end{abstract}

Keywords: private equity, venture capital, firm data

\section{Introduction}

Venture capital is seen as a key to promoting young, innovative companies. Such companies often possess potentially profitable investment projects, which in turn allow for a more productive usage of production factors (Lentz \& Mortensen, 2008). Hence, venture capital is regarded as a means to boost the development of an economy as a whole. However, many if not most developed economies are facing a lack of funding regarding young companies. The resulting equity gap may be defined as "difference between the amount of (risk) capital that would be invested under conditions of well-informed and competitive markets and the amount of capital actually invested" (Wilson et al., 2018).

An equity gap concerning young, innovative companies is especially damaging as it relates to a situation in which profitable projects exist which, however, cannot be pursued due to the lack of funding. International comparison studies show that, relative to their state of development and R\&D investments, European economies experience little venture capital investments. Within Europe, Austria lags even further behind. (Note 1) One potential explanation relates to historic origins, with Europe having a universal banking landscape with large banks covering commercial and investment banking activities (Demary et al., 2016). Banks typically prefer low-risk investments and show little interest in providing risk capital to young, innovative companies with a high chance to fail. The result is a situation in which firms with identical expected values but different chances of failure face different chances of receiving financing, as banks shy away from high risks. In contrast, the demand for capital market financing in the US is much more pronounced, resulting in more financing opportunities.

The EU's Capital Markets Union aims at reducing the dependency on banks by diversifying capital markets (Franke \& Krahnen, 2017). Indeed, SMEs' alternatives to bank loans have improved over the past years (OECD, 2018), and it should be stressed that equity ratios have increased in most EU member states since 2006, including Austria (Demary et al., 2016). Consequently, bank indebtedness has decreased. Despite these developments, European SMEs are still confronted with difficulties regarding alternatives to bank loans in general, and access to venture capital in particular (Lopez de Silanes Molina et al., 2015).

It comes as no surprise that governments have developed myriads of schemes to increase the availability of venture capital. The Republic of Austria (2011) has declared the recognition as an "innovation leader", based on an index constructed by the European Commission (2017), as an objective. The European Commission itself (ibid.) identifies the low volume of privately invested venture capital as one of Austria's major constraints achieving this objective. At the moment of writing Austria is developing a number of schemes in order to 
increase the volume of venture capital. Whether they will be successful largely depends on whether they will be able to alleviate existing market distortions.

The aim of the present paper is to identify market distortions regarding risk capital funding. To this end, the commercial database "Aurelia", as provided by Bureau van Dijk, is applied in order to generate empirical evidence. The paper is structured as follows. After the Introduction, the second Section discusses theory and empirical evidence regarding market distortions and failure in risk financing markets. After that, the third Section describes the database and provides some descriptive statistics. Results based on propensity score matching are presented and interpreted in the fourth Section. In the fifth Section, probit regression estimations are presented which hint at particular distortions in Austria. Some conclusions and an outlook can be found in the final Section.

It is not always clear what is exactly meant by the terms "risk capital", "venture capital" and "private equity". Private equity (PE) is typically considered as the investment in a particular company to make it more valuable before finally selling it ("exit"). Venture capital (VC) equity may be defined as private equity which is invested into young companies that are typically driven by technological innovation. It follows that $\mathrm{VC}$ is a sub-category of PE. To avoid confusion and adapt the present paper to the database which it applies, in what follows PE is regarded as private equity which is not $\mathrm{VC}$, while risk capital (RC) refers to both types (i.e. in this paper the three types may be expressed as: $\mathrm{RC}=\mathrm{PE}+\mathrm{VC}$ ).

\section{Market Imbalances and Failure in Risk Financing Markets}

An equity gap as defined in the Introduction may be considered a market failure in the sense that the society's goal of providing financing to young, innovative companies cannot be fully reached via market mechanisms alone. Such a failure is not due to a lack in total investments but rather due to the reluctance of investors to invest in companies with a high chance of failure despite such investments displaying, on average, a higher expected value. In other words, risk aversion is probably the main reason why Austria's share in VC is so low. Some indicators, such as the share of stocks in private assets - which equals only about the thirtieth part of private wealth in Austria - support this impression (see Keuschnigg \& Kogler, 2016). Another problem in the Austrian risk capital market relates to different taxes for equity and debt financing, favouring the latter over the former. Both risk aversion and taxing distortions may increase the total equity gap but should, nevertheless, affect all potential investees alike.

The problem of high risk is amplified by lack of information, with the equity gap resulting from the difficulties faced by a potential investor to evaluate a company's prospects of success as an outsider. To become an insider is a solution to the problem. As laid out by Cumming \& Johan (2016), severe information asymmetries and agency problems associated with financing startups in high-tech industries with little or no tangible assets let startups to depend on VC. Because startups face an uncertain future, often not having yet started to produce anything to be sold at the market place, intensive screening of business plans is indispensable for potential investors. This is true for private investors (either as privately-owned funds or as independent "business angels") as well as governmental venture capital funds: As a result of the uncertainties, risk capital is typically associated with human capital investments, too, as the investors are forced to put in a lot of effort in order to find those startups actually worth investing in. (Note 2)

The high-risk nature of startups combined with the necessity of investors to become closely related with the firm leads to a situation in which further forms of market failure may emerge, as the investors may be risk-neutral, but perhaps prone to their own preferences, subjective assessments, cultural distance or comfort. Arguably the best-known hypothesis in this context relates to the impact of national borders (Li et al., 2014). The European Investment Bank (2013) notes that despite the establishment of free movement of capital within the EU, differences regarding geographical location persist: Investors are much better informed regarding investment opportunities and risks at their own location. Differences regarding institutional, fiscal and regulatory framework conditions or language barriers as well as cultural peculiarities hinder cross-border investments. With venture capital investments being connected to control and consulting activities, they benefit from spatial proximity as well as existing networks (Lutz et al., 2013). It follows that an existing equity gap in Austria cannot be filled by foreign investments, at least not completely.

Geographical distortions are by no means limited to international borders. Rather, spatial concentration of companies financed by $\mathrm{VC}$ can be observed at the global, continental and national level. A few numbers underline this observation: The US accounted for 79 per cent of global venture capital investments in 2009, of which California accounts for 50 per cent, while Silicon Valley accounts for 80 per cent of VC investments received by Californian companies (Coe et al., 2013). Within Silicon Valley, firms centred on one single street, 
Sand Hill Road, dominate the venture capital industry, accounting for an astonishing third of the global total of VC in 2009 (ibid.). Recent studies indicate that the geographical concentration of venture capital in the US is increasing over time (Medcalfe \& Thompson, 2017). Within Europe, spatial concentration is also evident, albeit to a lesser degree. In 2016, 56.9 per cent of VC was invested either in France, Germany or the UK. (Note 3) Despite the establishment of the European Single Market most VC stays at home: 84.8 per cent of VC originating in French VC funds was invested domestically, so were 87.1 of German VC, 66.9 per cent of UK based VC and 68.6 per cent of Austrian VC.

Austria seems especially prone to geographically induced market distortions as the economy is dominated by Vienna. Due to its size, it is Vienna where the emergence of agglomeration effects is most likely to benefit high-tech industries. On the other hand, Austria is also characterised by relatively small interregional disparities concerning productivity, and hosts some export-oriented industrial districts in federal states such as Styria and Upper Austria. Despite these characteristics, over the past two decades some indicators point at increasing spatial inequality regarding human capital endowments, which are likely to be related to the location of particular industries as well as spatial density of workers (Sardadvar \& Hajji, 2016). This, in turn, hints at a growing importance of agglomerations for more sophisticated industries, assuming that they rely more on human capital than other less sophisticated industries.

Hence it might be argued that a spatial concentration regarding RC investment patterns would actually increase market efficiency by taking into account positive externalities created in urban economies. On the other hand, it is perhaps not so much the presence of agglomeration effects which matter in the present context but rather the effect if may have on investors' preferences. Consider a situation in which Vienna indeed offers certain effects external to the firm, such as existing networks or a superior infrastructure. Consider further that an investor is aware of this, and for this reason expects the most promising startups to originate in Vienna. Given the necessary geographical proximity of investor and investee for the reasons discussed above, the investor will prefer to locate in Vienna. Consequently, it will be easier for the investor to screen companies in or close to Vienna. The resulting market failure does not originate in a higher share of $\mathrm{VC}$ backed companies in Vienna, relative to other areas. Rather, the crucial point is the comparison of two otherwise identical companies which would not benefit from agglomeration effects: If the geographical location of investors is geographically biased as a result of their expectations, ceteris paribus a Viennese company has a higher chance of receiving VC. In other words, companies outside Vienna are disadvantaged and market failure prevails.

In addition to geography, access to risk capital may also be influenced by management composition. As with other socioeconomic relations, discrimination, network effects and trust may benefit some social groups more than others. Diversity is understood to have some impact on firm performance, but economic theory suggests that the effects of diversity on business performance are ambiguous (Nathan \& Lee, 2013): On the one hand, diverse teams may be better at generating ideas and solving problems, which seems particularly desirable for innovative firms. On the other hand, diversity may also increase communication costs and decrease trust, two issues which certainly matter in the case of risk financing when considering the involvement of investors in firm decisions. In the context of the present study it is, however, less relevant which effect outweighs the other but rather what investors are thinking.

Studies have shown that access to RC may indeed be influenced by attributes of potential investees. Lins \& Lutz (2016) show for Germany that female entrepreneurs receive less VC than male entrepreneurs. Tinkler et al. (2015) find for the US that men with technical degrees are awarded the most VC. Discrimination may also be due to ethnicity, where Bengtsson \& Hsu (2015) show for the US that shared ethnicity increases the probability of an investment match. While the aforementioned studies display a tendency that trust may outweigh potentially positive effects of diversity, Wilson et al. (2018) find a positive correlation of foreign directors with VC deals in the UK. In the case of Austria, same-language foreigners may be further distinguished from others, as Austria hosts less than a tenth of German native speakers while currently not restricting immigration from Germany and Switzerland as these countries are, together with Austria, part of the Schengen Area.

\section{Data and Descriptive Statistics}

The data for all analyses stem from the database "Aurelia" as provided by Bureau van Dijk, augmented by industry data as provided by Statistik Austria. The Aurelia database, which covers about 440,000 companies in Austria, has been edited to include as many variables as possible which are considered as relevant for receiving risk capital. (Note 4) Some attributes such as technology or market potential are captured indirectly by industry classification and the industry's R\&D share. Other attributes such as a company's size are captured by several variables, in this case registered share capital, number of employees, number of subsidiaries, among others. 
The variables originating in the Aurelia database are: location including address, six-digit ÖNACE industry code, (Note 5) revenue in 2017 or last available year, stock market listing yes/no, age since foundation, age since re-organisation, registered share capital in 2017 or latest available year, number of employees, revenue per employee, number of companies within group of companies, number of shareholders, number of subsidiaries, certificate of creditworthiness as publicised by Creditreform yes/no, (Note 6) number of managers, share of female managers, share of Austrian managers, share of German managers, share of Swiss managers, share of other foreign mangers, volume of venture capital, volume of private equity capital, import quota, export quota, foreign shareholders yes/no.

The subsequent statistical analyses consider only those companies for which data for all variables as listed above are available. After removing all companies with incomplete data 55,566 observations; remain, of which 145 companies display risk capital as part of their registered share capital, of which 50 display venture capital. The companies' addresses are transformed to their respective host districts and federal states, while the industry codes are given by the first digit. In addition, industry R\&D shares are included, referring to the industries at the three-digit level and in the case of some R\&D-intensive industries at the four-digit levell. (Note 7) Appendix A displays the arithmetic means for each variable for each of the three samples. RC and VC financed companies are, on average, by all indicators larger than the average firm of the complete sample. This is partly because some very large multinationals display $\mathrm{RC}$, but also because the complete sample includes many very small firms such as single-member companies. Other indicators imply that RC and VC financed companies are, as one would perhaps expect, indeed younger and also more international, as they are more export-oriented and there exist far more companies with foreign shareholders. Also worth mentioning are the considerably higher R\&D shares of RC and VC financed industries.

Further comparisons of the complete sample with the two subsamples reveal that some industries, as one would expect, are more favoured by risk investors than others. For instance, the ICT industry (code J) and professional, scientific and technical activities (code $\mathrm{M}$ ) attract much more risk and venture capital than would be expected from the complete sample. Interestingly, financial and insurance activities (code $\mathrm{K}$ ) receive more often $\mathrm{RC}$, but less often VC than firms in the complete sample. Furthermore, manufacturing (code C) is: well represented in the two subsamples, but, on the other hand, not a single observation is classified as construction (code F).

Concerning geography, Vienna is clearly overrepresented in the RC and VC financed groups, hosting less than a quarter of the complete sample's companies, but over two fifths of the RC and VC financed companies. In contrast, especially Lower Austria, Carinthia and Tyrol seem underrepresented. Figure 1 displays maps of Austria's currently 94 districts and the respective numbers of RC and VC financed firms of the two sub-samples. The first feature which catches the eye is Vienna's dominant position. Apart from that, two patterns are worth mentioning. First, within the other federal states RC and VC financed firms tend to be either clustered in the larger cities, or in the industrial zones of Upper Austria and Styria. Second, within Lower Austria, most RC and VC financed firms are located in districts which are adjacent to Vienna. Both patterns support the impression that startups in rural areas are, ceteris paribus, disadvantaged.
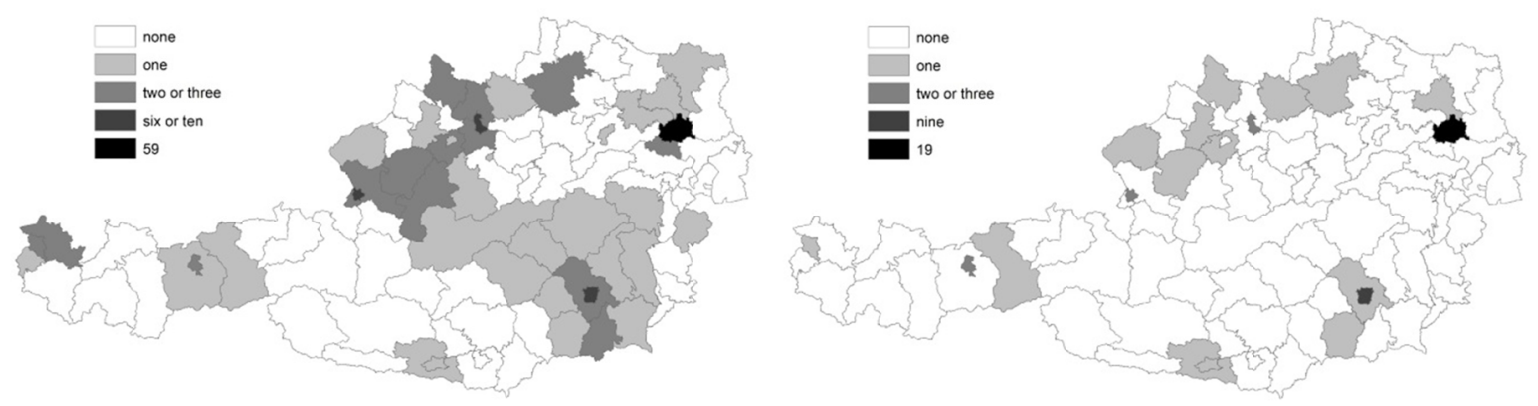

Figure 1. Geographical distribution of risk [left] and venture [right] capital financed companies

Note. Geodata as provided by Statistik Austria. 


\section{Propensity Score Matching}

The first empirical step corresponds to propensity score matching analyses in order to compare those companies which actually have received RC to companies with similar or identical attributes. The method follows Wilson et al. (2018), which is based on Alperovych et al. (2015). The first group of companies is typically referred to as "treated group", as having received a form of treatment that distinguishes it from the rest - in the present case, the subsamples which are RC financed or VC financed. The second group is referred to as "control group". The propensity score matching's purpose is to construct samples of companies which serve as control groups and are as similar as possible to the treated groups. In contrast to a sample based purely on a randomised selection the propensity score matching analysis acknowledges the impact of various variables which increase the likelihood of receiving the treatment, e.g. R\&D intensity. Therefore, the bias due to confounding variables is reduced. After the matching procedure, the treated and control groups can be compared. (Note 8)

In order to avoid geographically induced bias, in the propensity score matching procedure location data will not be considered. Furthermore, instead of industry codes the industries' R\&D shares are considered corresponding to a three-digit classification, in the case of some R\&D-intensive industries corresponding to a four-digit classification. (Note 9) In other words, the variables actually applied in the propensity score matching procedure correspond to the first 21 lines of Appendix A ("revenue" to "R\&D share").

Two different propensity score matching methods are applied. The first corresponds to the "nearest neighbour" method which selects a number of best control matches for each observation in the treated group. Matching is done using a logistic regression model to estimate the propensity score, defined as the probability of receiving treatment (i.e., RC or $\mathrm{VC}$ investment), conditional on the covariates. The matching is done with $\mathrm{R}$, using the package MatchIt. (Note 10) The second method corresponds to the "genetic" method which selects a control group that resembles the treated observations a closely as possible as a group. This is in contrast to the "nearest neighbour" method which seeks observations which resemble the particular observations of the treated group. Therefore, one would typically expect the "nearest neighbour" method to produce more outliers within the group but representing the individuals of the treated group more closely, and vice versa. The "genetic" matching is also done in R, using the package Matching. (Note 11)

It follows that (i) the control groups are expected to be similar to the treated groups expect for whether having received RC or VC and (ii) the "nearest neighbour" control group is expected to be closer to the treated group with respect to the average propensity score, but farther away with respect to all other variables than the "genetic" group. The propensity score matching results are documented in detail in Appendix B. The described expectation holds true. The variable "age of foundation" is an illustrative example how the variables values are similar for the treated and the "genetic" control groups, while deviating relatively stronger for the "nearest neighbour" control group. This holds generally true for all variables but due to the larger sample sizes the risk capital control groups resemble the treated group better than the venture capital groups.

The average propensity score (or "distance") of 0.454 is indeed almost identical for the RC "nearest neighbour" control group and the RC treated group, as the value for the latter equals 0.0453 (not displayed in the Appendix). In the case of the $\mathrm{VC}$ groups, the average propensity score of the treated group equals 0.0348 , which is also much closer to the values of the VC "nearest neighbour" control group than its "genetic" counterpart. It should be stressed that propensity scores of the VC treated group and "nearest neighbour" control group are not almost identical in most cases because the latter's sample size is very small.

The propensity score matching's most important information is given by the values for those variables which were not considered in the propensity score matching process as such, i.e. the distributions across industries and federal states. Regarding the RC control groups, the shares of the construction industry (code F) and the accommodation and food service activities (code I) in the treated groups suggest that these industries would qualify for at least some RC. In contrast, the much higher share of the manufacturing sector (code C) as well as professional, scientific and technical activities (code M) in the treated group seems to be justified, as the control groups display similarly high numbers.

The venture capital control groups show a similar picture except for the ICT industry (code J), which displays even higher shares surpassing $40 \%$ in the treated group and the "genetic neighbour" control group, while the share in the "nearest neighbour" control group is smaller than $10 \%$, indicating that this industry is perhaps receiving over-attention from investors. In contrast, professional, scientific and technical activities (code M) reaches even higher shares in the "nearest neighbour" control group, indicating that despite the high number of investees, it would perhaps deserve even more attention. Note, however, that the sample sizes of the venture capital groups are much smaller and statistics should be interpreted with caution. 
Table 1. Regression results risk capital

\begin{tabular}{|c|c|c|c|}
\hline & Model I & Model II & Model III \\
\hline Intercept & $-3.933 * * *(0.000)$ & $-3.784 * * *(0.000)$ & $-4.120 * * *(0.000)$ \\
\hline Revenue & $-0.393 * *(0.016)$ & $-0.382 * *(0.023)$ & $-0.449 * * *(0.008)$ \\
\hline Stock market listing & $-0.107(0.674)$ & $-0.200(0.441)$ & $-0.223(0.393)$ \\
\hline Age since foundation & $-0.121(0.114)$ & $-0.136^{*}(0.087)$ & $-0.144 *(0.079)$ \\
\hline Age since re-organisation & $-0.204 * * *(0.008)$ & $-0.193 * *(0.016)$ & $-0.180 * *(0.027)$ \\
\hline Reg. share capital & $0.021(0.379)$ & $0.024(0.336)$ & $0.033(0.187)$ \\
\hline Employees & $0.472 * * *(0.005)$ & $0.454 * * *(0.009)$ & $0.517 * * *(0.003)$ \\
\hline Revenue/employee & $0.386 * *(0.029)$ & $0.376^{* *}(0.039)$ & $0.463 * *(0.011)$ \\
\hline Companies & $0.015(0.485)$ & $0.008(0.702)$ & $0.012(0.592)$ \\
\hline Shareholders & $0.628 * * *(0.000)$ & $0.651 * * *(0.000)$ & $0.640 * * *(0.000)$ \\
\hline Subsidiaries & $0.026 *(0.090)$ & $0.027 *(0.079)$ & $0.025(0.113)$ \\
\hline Managers & $0.125(0.149)$ & $0.123(0.161)$ & $0.125(0.162)$ \\
\hline Female managers & $-0.376^{* *}(0.049)$ & $-0.364 *(0.062)$ & $-0.331 *(0.096)$ \\
\hline Austrian managers & $0.410 * *(0.042)$ & $0.377 *(0.066)$ & $0.338(0.105)$ \\
\hline German managers & $0.233(0.363)$ & $0.209(0.421)$ & $0.178(0.501)$ \\
\hline Import quota & $-0.002(0.263)$ & $-0.002(0.199)$ & $-0.001(0.482)$ \\
\hline Export quota & $0.005 * * *(0.000)$ & $0.005^{* * *}(0.000)$ & $0.004 * * *(0.002)$ \\
\hline Foreign shareholders & $0.706 * * *(0.000)$ & $0.758 * * *(0.000)$ & $0.726 * * *(0.000)$ \\
\hline Vienna & $0.157 * *(0.032)$ & & \\
\hline $\mathrm{VN}$ & & $-0.040(0.816)$ & $0.013(0.940)$ \\
\hline Lower Austria w/o VN & & $-0.432 * *(0.010)$ & $-0.393^{* *}(0.025)$ \\
\hline Burgenland & & $-0.426(0.233)$ & $-0.411(0.264)$ \\
\hline Styria & & $0.103(0.331)$ & $0.156(0.152)$ \\
\hline Carinthia & & $-0.559 * *(0.038)$ & $-0.496 *(0.065)$ \\
\hline Tyrol & & $-0.618 * * *(0.001)$ & $-0.582 * * *(0.003)$ \\
\hline Upper Austria & & $0.049(0.613)$ & $0.092(0.356)$ \\
\hline Salzburg & & $-0.178(0.236)$ & $-0.115(0.450)$ \\
\hline Vorarlberg & & $-0.315 *(0.076)$ & $-0.240(0.186)$ \\
\hline R\&D share & $1.574 * * *(0.000)$ & $1.482 * * *(0.000)$ & $0.891 *(0.058)$ \\
\hline Industry C & & & $0.211 *(0.051)$ \\
\hline Industry $\mathrm{J}$ & & & $0.572 * * *(0.000)$ \\
\hline Industry $\mathrm{M}$ & & & $0.243 * *(0.045)$ \\
\hline$L I K$ & -707.2 & -690.8 & -676.5 \\
\hline$A I C$ & 1454.3 & 1437.5 & 1414.9 \\
\hline
\end{tabular}

Notes. "VN" is short for the districts neighbouring Vienna; for industry codes see Appendix A. The estimations have been carried out with R using the AER package 1.1-7. Standard errors are in parentheses, probability values $p$ displayed by $* * *$ if $p \leqslant 0.01, * *$ if $p \leqslant 0.05, *$ if $p$ $\leqslant 0.1$. LIK and $A I C$ refer to the values of the maximised log-likelihood and Akaike information criterion, respectively.

A comparison across federal states reveals that Vienna seems to be overrepresented regarding actual RC and VC investments, as the actual shares are much higher than the control groups'. Examples of the opposite case are given by Tyrol and Lower Austria, which seem to be underrepresented by the actual numbers. Note that the other two federals states which display notable shares of RC and VC, Styria and Upper Austria, receive high shares in the control groups, too, which suggests that these states' actual shares are justified.

\section{Probit Regressions}

As a next step, probit regressions are run in order to test to what extent the deviations as displayed in Appendix B can be justified by the companies' characteristics. As with the propensity score matching process, the dependent variable equals one if a company has received $\mathrm{RC}$ or $\mathrm{VC}$, zero else. The explanatory variables are the same as above, i.e. as given in Appendix A, with the applied sample corresponding to the "complete sample", i.e. including all 55,566 observations for which complete data exist. (Note 12) The variables creditworthiness and Swiss managers are not included in the regressions because of only one observation of the former variable in the $\mathrm{RC}$ subsample, zero observations in the VC subsample, and zero observations of the latter variable in both the $\mathrm{RC}$ and the VC subsample (see Appendix A). Table 1 displays the results for the regressions based on RC as the dependent variable. Model I of Table 1 corresponds to a regression specification in which Vienna is the only 
federal state considered explicitly and the industries as such are not included. Model I provides the basic results, which may be summarised as follows: (Note 13)

- The more recent a company's foundation or re-organisation (i.e. the lower the age), the higher the probability of receiving RC. Likewise, the number as well as the existence of foreign shareholders increase the probability. Concerning size, the number of employees has a positive, while total revenue has a negative, and total equity has no significant impact. In contrast, revenue per employee is positive. Together, these results suggest that young and productive companies are more likely to receive RC.

- The presence of female as well as foreign managers outside the German-language world (i.e. non-Austrian and non-German) decreases the chance of receiving RC. Furthermore, the chances of receiving RC increase with a company's export share, while the import share has no significant impact. It could be said that internationality has a positive effect when it comes to a company's relations, but not with respect to its management. Whether the negative impacts of female and foreign managers are due to investors' preferences, or whether they are due to the managers' competences, which are in turn correlated with other, unmeasured variables, cannot be assessed (see below for a further discussion).

- Both Vienna as a location and R\&D shares have positive and significant coefficients. The impression given in the previous Section is confirmed: To be located in Vienna has a positive impact on the chance of receiving RC beyond attributes internal to the firm. The positive impact of the R\&D share confirms the impression that $\mathrm{RC}$ is associated with innovative companies.

In Model II, Vienna is replaced by the other federal states in order to see which states are possibly disadvantaged. In addition, as a consequence of the relatively frequent occurrence of RC backed companies around Vienna, those districts which are geographically adjacent to Vienna are split from the federal state of Lower Austria, indicated as "VN" (Vienna Neighbourhood). It can be seen that Lower Austria without VN indeed displays a negative and significant coefficient, which is not the case for VN. Other regions with negative and significant signs are Carinthia, Tyrol and Vorarlberg. The only regions with positive signs are Upper Austria and Styria, though not statistically significant at the $10 \%$ level.

Finally, in Model III those three industries (manufacturing, ICT and professional, scientific and technical activities) which together represent over two thirds of all RC financed companies are included explicitly in the regressions. They indeed have positive and significant coefficients, of which the ICT industry coefficient (code J) takes on the highest value. It should be noted that the significant coefficients of federal states as well as the R\&D share variable which are significant in Model II remain so in Model III, although their standard errors increase.

Table 2 gives estimates of the same models as in Table 1, but with VC as the dependent variable. In other words, the dependent variable $=1$ if a company includes $\mathrm{VC}$ in its registered share capital. Due to the small number of VC backed companies, fewer coefficients are statistically significant at the $10 \%$ level and type II errors (not rejecting the hypothesis that a coefficient equals zero although it does not) are relatively likely. For these reasons, $p$-values slightly above 0.1 also get a mention (for a discussion see Verbeek, 2009). In general, the results of Table 2 are comparable to those in Table 1, but some notable differences exist:

- Revenue per employee seems to have no effect on VC financing, while the number of companies has a negative impact. The sign of the number of subsidiaries switches from positive to negative and is significant at least at the $10 \%$ level in each case.

- Neither the export nor the import share have impacts worth mentioning, but the presence of foreign shareholders remains significant, statistically even at the $0.1 \%$ level. The sign of the share of female managers remains negative, but the standard errors increase the more variables are included. In similar vein, no impact of the managers' nationalities can be detected.

- The positive sign of Vienna remains, but its statistical significance levels decrease. Lower Austria without VN, Tyrol and Vorarlberg keep their negative coefficients. Interestingly, Styria displays a positive and significant sign. Regarding industries, only ICT displays a positive and significant impact.

To summarise, results for $\mathrm{RC}$ and $\mathrm{VC}$ are comparable in general, but show interesting differences regarding details. The basic expectations one might have before conducting a study, e.g. that $\mathrm{RC}$ and $\mathrm{VC}$ prefer young, innovative companies, are confirmed. Furthermore, company size has an impact, but revenue alone is not sufficient: When controlling for revenue per employee as well as other variables associated with size, revenue as such is negative. The overall impression here is that productivity matters, but size as such does not.

What seems puzzling is, first, that the roles of the managers' sexes and nationalities are relevant for RC investments, but not in the case of VC. It should be stressed, however, that in the latter subsample only seven 
companies feature female, only five feature German, and only four feature other foreign managers. Therefore, a statistical assessment becomes difficult, although it should be mentioned that the coefficients regarding female and Austrian managers in the VC estimations have the same signs as in the RC estimations.

Second, the dominant situation of Vienna is a reason for concern, but it seems less pronounced regarding VC, too. Whereas Lower Austria, Tyrol and Vorarlberg clearly seem to be disadvantaged with respect to both RC and VC, this is not the case for Styria and Upper Austria. Whether these two federal states are doing relatively well because of regional industrial policies, or because of their economic structure - or both - seems worth investigating in future studies. A candidate explanation for the reduced impact of Vienna is the inclusion of R\&D shares in the regressions. Therefore, Vienna as a preferred location for high-technology firms and the associated agglomeration effects may be sufficient in the case of $\mathrm{VC}$, but not $\mathrm{RC}$ investments.

Finally, it should be pointed out that due to limitations of the database, only present correlations can be considered. For instance, whether the negative impact of female manager shares is really due to investors' preferences, or whether such companies have been less successful in the past and gone out of business more frequently - for reasons yet to be studied - remains unclear. Similar reasoning applies for the detected roles of foreign manager shares and, in particular, location. Furthermore, only investments into registered share capital are considered, although other forms of RC and VC investments are also possible. What the present study can provide, however, is evidence that these correlations do exist, and that they deserve a deeper investigation.

Table 2. Regression results venture capital

\begin{tabular}{|c|c|c|c|}
\hline & Model I & Model II & Model III \\
\hline Intercept & $-4.278^{* * *}(0.000)$ & $-4.317^{* * *}(0.000)$ & $-5.006^{* * *}(0.000)$ \\
\hline Revenue & $-0.250(0.331)$ & $-0.219(0.432)$ & $-0.342(0.189)$ \\
\hline Stock market listing & $0.180(0.665)$ & $0.112(0.801)$ & $0.136(0.767)$ \\
\hline Age since foundation & $-0.049(0.679)$ & $-0.094(0.456)$ & $-0.108(0.436)$ \\
\hline Age since re-organisation & $-0.267 * *(0.027)$ & $-0.235 *(0.071)$ & $-0.212(0.125)$ \\
\hline Reg. share capital & $0.039(0.382)$ & $0.043(0.345)$ & $0.082 *(0.088)$ \\
\hline Employees & $0.340(0.199)$ & $0.296(0.304)$ & $0.407(0.134)$ \\
\hline Revenue/employee & $0.174(0.541)$ & $0.145(0.637)$ & $0.289(0.325)$ \\
\hline Companies & $-0.069(0.102)$ & $-0.077 *(0.075)$ & $-0.078 *(0.097)$ \\
\hline Shareholders & $0.652 * * *(0.000)$ & $0.683 * * *(0.000)$ & $0.670 * * *(0.000)$ \\
\hline Subsidiaries & $-0.066 * *(0.048)$ & $-0.068 * *(0.049)$ & $-0.067 *(0.060)$ \\
\hline Managers & $0.103(0.488)$ & $0.100(0.514)$ & $0.099(0.557)$ \\
\hline Female managers & $-0.350(0.230)$ & $-0.297(0.319)$ & $-0.240(0.462)$ \\
\hline Austrian managers & $0.185(0.513)$ & $0.178(0.543)$ & $0.021(0.945)$ \\
\hline German managers & $-0.123(0.766)$ & $-0.104(0.803)$ & $-0.227(0.609)$ \\
\hline Import quota & $>0.000(0.882)$ & $-0.001(0.823)$ & $0.001(0.661)$ \\
\hline Export quota & $0.001(0.834)$ & $>0.000(0.876)$ & $>0.000(0.918)$ \\
\hline Foreign shareholders & $0.848 * * *(0.000)$ & $0.965^{* * *}(0.000)$ & $0.887 * * *(0.000)$ \\
\hline Vienna & $0.081(0.504)$ & & \\
\hline $\mathrm{VN}$ & & $-0.181(0.620)$ & $-0.135(0.732)$ \\
\hline Lower Austria w/o VN & & $-1.044 * *(0.024)$ & $-1.057 * *(0.041)$ \\
\hline Burgenland & & $-4.045(0.975)$ & $-4.175(0.972)$ \\
\hline Styria & & $0.390 * *(0.015)$ & $0.517 * * *(0.003)$ \\
\hline Carinthia & & $-0.041(0.885)$ & $0.098(0.737)$ \\
\hline Tyrol & & $-0.341(0.159)$ & $-0.290(0.275)$ \\
\hline Upper Austria & & $0.087(0.610)$ & $0.185(0.309)$ \\
\hline Salzburg & & $-0.090(0.719)$ & $0.002(0.996)$ \\
\hline Vorarlberg & & $-0.594(0.130)$ & $-0.342(0.382)$ \\
\hline$R \& D$ share & $1.910^{* * *}(0.000)$ & $1.816^{* * *}(0.000)$ & $2.286^{* *}(0.022)$ \\
\hline Industry C & & & $0.127(0.556)$ \\
\hline Industry J & & & $0.871^{* * *}(0.000)$ \\
\hline Industry $\mathrm{M}$ & & & $-0.023(0.939)$ \\
\hline LIK & 257.1 & -244.2 & 225.1 \\
\hline AIC & 554.2 & 544.3 & 512.1 \\
\hline
\end{tabular}

Notes. See Table 1. 


\section{Conclusions and Outlook}

The European Union lags behind regarding risk capital investments, and Austria lags behind within the European Union. Both the European Union and the Republic of Austria have recognised this challenge, as it hinders the development of young, innovative companies which are understood as drivers of future economic growth. The European Commission (2017) identifies the low volume of privately invested venture capital as one of Austria's major constraints in achieving its self-declared goal of being recognised as an "innovation leader". The problems associated with providing sufficient risk capital may also be regarded as a market failure, as the society's goal of startup financing cannot be provided via market mechanisms. The main reason seems to be that, despite providing higher returns on average, too few investors are willing to risk the associated and more frequent total losses.

What can be done? The present article provides some evidence on what makes firms more likely to receive risk capital (which is the same as private equity by some definitions) and venture capital (which is a sub-category of risk capital or private equity devoted to young, innovative companies). To this end, propensity score matching analyses as well as probit regression estimations were undertaken. Some results are as expected: Companies which are young, innovative and productive have a higher chance of receiving risk and venture capital.

Other results are partly surprising and reasons for concern. First, the present study provides some evidence that Vienna as a startup's location ceteris paribus increases the chance of receiving risk capital. Both the propensity score matching analysis as well as probit regressions suggest that the disproportionately high share of Vienna as a host to risk financed companies is not fully justified by the respective companies' attributes. To be sure, this result can be well explained by theory: Investors prefer to settle close to potential investees, who in turn settle close to available investors. This interplay provokes a self-amplifying process, which makes it even harder for companies outside Vienna to receive risk capital. On the one hand, the respective investors' behaviour may be justified by the presence of agglomeration effects, which have the potential to make firms indeed more productive, and, therefore, represent rationality. On the other hand and more alarmingly, it may as well be that out of two otherwise identical firms, which for technological reasons do not benefit from agglomeration effects, the one outside Vienna has a lesser chance of receiving risk capital simply because the investors are located in Vienna and prefer proximate candidates or perhaps even ignore companies outside Vienna.

Second, the present study also provides some evidence that companies with Austrian and male managers are preferred by investors. As with location, this result may well be due to correlations with unobserved variables. Among these perhaps the most likely are network effects, in particular if most investors happen to be male and Austrian themselves. As with agglomeration affects, the observed preference for male and Austrian managers may be to the disadvantage of firms whose managements are more female and foreign, but considering trust associated with networks, it may be rational from the investor's point of view. But then, if two firms happen to be identical except for the management's diversity, the less diverse one has a greater chance of receiving risk capital. Under such circumstances a self-amplifying process may be the consequence in which talent of women and foreigners is being wasted if the respective firms are not financed.

Due to the database's limitations, inferences from the present study are limited. Most important, the study is not able to interpret the developments of companies as the data represents a snap-shot of the currently existing companies. Therefore, it may as well be that investors are in no way biased by a startup's location or management's composition, but the estimated effects are actually due to differences regarding economic success. Either way, the present study should be regarded as a motivation for future research. Considering that governments in most developed countries are willing to use public money for various schemes subsidising startups, a balanced distribution of these means is by any means necessary.

\section{Acknowledgments}

The present paper is based on and further extends the study "Steuerbegünstigungen für Mittelstandsfinanzierungs-gesellschaften neu (,MiFiG neu“) nach dem Mittelstandsfinanzierungsgesellschaften-Gesetz (MiFiG-G) 2017" by order of the Austrian Federal Ministry of Science, Research and Austrian Economy and the Federal Ministry of Finance, conducted at WPZ Research, Vienna, by Christian Keuschnigg and Sascha Sardadvar. The author of the present article wishes to thank the ministries for financing, Brigitte Ecker and Christian Keuschnigg for their support, and two referees for their suggestions.

\section{References}

Alperovych, Y., Hübner, G., \& Lobet, F. (2015). How Does Governmental Versus Private Venture Capital Backing Affect a Firm's Efficiency? Evidence from Belgium, Journal of Business Venturing, 30, 508-525. 
https://doi.org/10.1016/j.jbusvent.2014.11.001

Bengtsson, O., \& Hsu, D. H. (2015): Ethnic matching in the U.S. venture capital market, Journal of Business Venturing, 30(2), 338-354. https://doi.org/10.1016/j.jbusvent.2014.09.001

Best, H., \& Wolf, C. (2010): Logistische Regression. In H. Best \& C. Wolf (Eds.), Handbuch der sozialwissenschaftlichen Datenanalyse (pp. 827-854.) Wiesbaden, Germany: VS Verlag.

Coe, N. M., Kelly, P. F., \& Yeung, H. W. C. (2013). Economic geography: A contemporary introduction (2nd ed.). Hoboken [NJ], USA: Wiley

Cumming, D. J., \& Johan, S. A. (2016). Venture's economic impact in Australia. Journal of Technology Transfer 41, 25-59. https://doi.org/10.1007/s10961-014-9378-3

Demary, M., Hornik, J., \& Watfe, G. (2016). SME Financing in the EU: Moving Beyond One-Size-Fits-All. Bruges European Economic Policy Briefings 40/2016.

Diamond, A., \& Sekhon, J. S. (2013). Genetic matching for estimating causal effects: A general multivariate matching method for achieving balance in observational studies. Review of Economics and Statistics, 95, 932-945. https://doi.org/10.1162/REST_a_00318

European Investment Bank. (2013). Investment and Investment Finance in Europe. Luxembourg, Luxembourg: European Investment Bank.

European Commission. (2017). European Innovation Scoreboard 2016. Brussels, Belgium: European Commission.

Franke, G., \& Krahnen, J. P. (2017). SME funding without banks? On the interplay of banks and markets. White Paper Series, No. 44.

Ho, D. E., Imai, K., King, G., \& Stuart, E. (2011). MatchIt: nonparametric preprocessing for parametric causal inference, Journal of Statistical Software, 42(8).

Keuschnigg, C., \& Kogler, M. (2016). Finanzplatz Österreich, Studie, WPZ St. Gallen-Wien. Retrieved from http://www.wpz-fgn.com

Keuschnigg, C., Ecker, B., Sardadvar, S., \& Reiner, C. (2017). Innovationsland Österreich - F\&E, Unternehmensentwicklung und Standortattraktivität, Studie für den Rat für Forschung und Technologieentwicklung, WPZ St. Gallen-Wien. Retrieved from http://www.wpz-fgn.com/wp-content/uploads/InnovationslandOesterreich20170606final-1.pdf

Lentz, R., \& Mortensen, D. T. (2008). An empirical model of growth through product innovation, Econometrica, 76, 1317-1373.

Li, Y., Vertinsky, I. B., \& Li, J. (2014). National distances, international experience, and venture capital investment performance, Journal of Business Venturing, 29, 471-489. https://doi.org/10.3982/ECTA5997

Lins, E., \& Lutz, E. (2016) Bridging the gender funding gap: do female entrepreneurs have equal access to venture capital?, International Journal of Entrepreneurship and Small Business, 27(2-3), 347-365. https://doi.org/10.1504/IJESB.2016.073993

Lopez de Silanes Molina, F., McCahery, J., Schoenmaker, D., \& Stanisic, D. (2015). European capital markets, study estimating the financing gaps of SMEs. Amsterdam, Netherlands: Duisenberg School of Finance.

Lutz, E., Bender, M., Achleitner, A. K., \& Kaserer, C. (2013). Importance of spatial proximity between venture capital investors and investees in Germany. Journal of Business Research, 66, 2346-2354. https://doi.org/10.1016/j.jbusres.2012.04.016

Medcalfe, S. K., \& Thompson, M. A. (2017): Further evidence on the geographical concentration of venture capital investments, Letters in Spatial and Resource Sciences, 10, 229-235. https://doi.org/10.1007/s12076-017-0184-z

Nathan, M., \& Lee, N. (2013): Cultural diversity, innovation, and entrepreneurship: Firm-level evidence from London, Economic Geography, 89(4), 367-394. https://doi.org/10.1111/ecge.12016

OECD. (2015). Entrepreneurship at a glance 2015. Paris, France: OECD Publishing.

OECD. (2018). Financing SMEs and entrepreneurs 2018: An OECD scoreboard. Paris, France: OECD Publishing.

Randolph, J. J., Falbe, K., Manuel, A. K., \& Balloun, J. L. (2014). A step-by-step guide to propensity score 
matching in R. Practical Assessment, Research \& Evaluation, 19(18).

Republic of Austria. (2011). Der Weg zum Innovation Leader - Strategie der Bundesregierung für Forschung, Technologie und Innovation. Vienna, Austria: The Republic of Austria.

Sardadvar, S., \& Hajji, A. (2016). The long run interregional distribution of human capital in Austria: What role for knowledge intensity of production? Mitteilungen der Österreichischen Geographischen Gesellschaft, $158,167-192$

Sekhon, J. S. (2011). Multivariate and propensity score matching software with automated balance optimization: the matching package for R, Journal of Statistical Software, 42, 1-52.

Tinkler, J. E., Whittington, K. B., Ku, M. C., \& Davies, A. R. (2015): The effects of technical background and social capital on entrepreneurial evaluations, Social Science Research, 51, 1-16. https://doi.org/10.1016/j.ssresearch.2014.12.008

Verbeek, M. (2008). A guide to modern econometrics (3rd ed.). Chichester, Great Britain: John Wiley \& Sons.

Wilson, N., Wright, M., \& Kacer, M. (2018). The equity gap and knowledge-based firms. Journal of Corporate Finance, forthcoming. https://doi.org/10.1016/j.jcorpfin.2017.12.008

\section{Notes}

Note 1. Measures of venture capital investments depend on definitions of venture capital as well as data availability. Due to its small volume in some countries it may also appear very volatile. International comparisons show in general that the ten countries with the highest GDP shares of venture capital investments include Israel, the USA, Canada, South Korea, South Africa, Japan and Switzerland as non-EU countries plus Sweden, Finland, Ireland and the UK as EU member states. Austria typically displays values which are comparable to the EU's southern and eastern member states, i.e. much lower than other economic indicators, in particular GDP per capita and R\&D investments, would suggest. For the data, see OECD (2015, Fig. 7.1); for a discussion of Austria's strengths and weaknesses as a location for innovation, see Keuschnigg et al. (2017).

Note 2. According to Cumming and Johan (2016, pp. 27), "Fund managers typically see over a thousand business plans per year for requests for capital, seriously consider fewer than 50 investments, and eventually carry out 1-2 new deals per year until the fund is fully invested."

Note 3. Data source in this paragraph if not cited otherwise: INVEST Europe; note: In this dataset "Europe" corresponds to the EU and some other large European economies including Norway, Switzerland and Ukraine, but excluding Russia and Turkey.

Note 4. The database is permanently updated, the data used in the present study were downloaded on 5-September 2017.

Note 5. The current ÖNACE 2008 corresponds to the international classification NACE Rev. 2.

Note 6. Creditreform is a German credit bureau and debt collection agency.

Note 7. Data source: Statistik Austria, Ausgaben für Forschung und experimentelle Entwicklung (F\&E) 2007-2015 nach Wirtschaftszweigen, downloaded 13-September-2017.

Note 8. Even though just about one eighth of the companies found in the database are actually used, the propensity score matching and subsequent analyses will not be biased. This is because 55,566 observations constitute a giant pool to select control groups in relation to the 145 and 50 observations of the treated group.

Note 9. The industries' R\&D shares are available from Statistik Austria and refer to the year 2013, downloaded on 13-September-2017.

Note 10. For details on the package and the method see Ho et al. (2011) and Randolph et al. (2014).

Note 11. For details on the package and the method see Sekhon (2011) and Diamond and Sekhon (2013).

Note 12. Explanatory variables whose values may be $>1$ are logarithmised for scaling reasons (revenue, age since foundation, age since re-organisation, registered share capital, employees, revenue/employee, companies, shareholders, subsidiaries, managers). In order to avoid undefined numbers, to the original values have been added the values of 0.01 (managers), 0.5 (age since foundation, age since re-organisation) or 1 (all other variables as listed above). 
Note 13. In contrast to linear regressions, coefficients of logistic regressions are difficult to interpret meaningfully (Best und Wolf, 2010). For this reason, the present discussion generally only comments on the direction and significance of coefficients. Comments on the coefficients' values are only given if a group of variables is compared, such as the binary industry variables.

\section{Appendix A}

Descriptive statistics, complete sample and subsamples

\begin{tabular}{|c|c|c|c|}
\hline & Complete sample & RC financed & VC financed \\
\hline Revenue $\left(€^{\prime} 000\right)$ & 18,308 & 323,530 & 31,077 \\
\hline Stock market listing (1 if yes) & 0.0013 & 0.0759 & 0.0600 \\
\hline Age since foundation & 24.55 & 18.43 & 15.24 \\
\hline Age since re-organisation & 18.31 & 14.27 & 12.02 \\
\hline Reg. share capital (€'000) & 847 & 17,755 & 25,175 \\
\hline Employees (number) & 31.72 & 112.04 & 67.92 \\
\hline Revenue/employee (€`000) & 903.83 & $1,066.1$ & 333.58 \\
\hline Companies (number) & 32.69 & 65.97 & 33.98 \\
\hline Shareholders (number) & 1.940 & 8.324 & 10.60 \\
\hline Subsidiaries (number) & 0.690 & 13.159 & 15.34 \\
\hline Creditworthiness ( 1 if yes) & 0.0074 & 0.0069 & 0.0000 \\
\hline Managers (number) & 1.5300 & 3.269 & 2.6800 \\
\hline Female managers & 0.1181 & 0.0580 & 0.0584 \\
\hline Austrian managers only & 0.9529 & 0.9117 & 0.9044 \\
\hline German managers & 0.0262 & 0.0549 & 0.0434 \\
\hline Swiss managers & 0.0048 & 0.0000 & 0.0000 \\
\hline Other foreign mangers & 0.0154 & 0.0375 & 0.0522 \\
\hline Import quota & 0.0960 & 0.1065 & 0.0760 \\
\hline Export quota & 0.0500 & 0.1755 & 0.1090 \\
\hline Foreign shareholders ( 1 if yes) & 0.1169 & 0.6483 & 0.7200 \\
\hline$R \& D$ share & 0.0277 & 0.0712 & 0.0965 \\
\hline Industry A & $0.45 \%$ & $0.00 \%$ & $0.00 \%$ \\
\hline Industry B & $5.74 \%$ & $0.69 \%$ & $2.00 \%$ \\
\hline Industry $\mathrm{C}$ & $13.54 \%$ & $22.07 \%$ & $16.00 \%$ \\
\hline Industry D & $0.58 \%$ & $0.69 \%$ & $2.00 \%$ \\
\hline Industry E & $0.71 \%$ & $0.69 \%$ & $0.00 \%$ \\
\hline Industry F & $16.37 \%$ & $0.00 \%$ & $0.00 \%$ \\
\hline Industry $\mathrm{G}$ & $26.63 \%$ & $15.17 \%$ & $10.00 \%$ \\
\hline Industry $\mathrm{H}$ & $4.65 \%$ & $0.69 \%$ & $0.00 \%$ \\
\hline Industry I & $5.44 \%$ & $0.00 \%$ & $0.00 \%$ \\
\hline Industry $\mathrm{J}$ & $5.55 \%$ & $23.45 \%$ & $46.00 \%$ \\
\hline Industry K & $3.77 \%$ & $9.66 \%$ & $2.00 \%$ \\
\hline Industry L & $4.76 \%$ & $1.38 \%$ & $2.00 \%$ \\
\hline Industry M & $12.12 \%$ & $22.07 \%$ & $18.00 \%$ \\
\hline Industry $\mathrm{N}$ & $5.13 \%$ & $3.45 \%$ & $2.00 \%$ \\
\hline Vienna & $24.28 \%$ & $41.38 \%$ & $40.00 \%$ \\
\hline Lower Austria & $15.93 \%$ & $6.21 \%$ & $2.00 \%$ \\
\hline Burgenland & $2.51 \%$ & $0.69 \%$ & $0.00 \%$ \\
\hline Styria & $11.26 \%$ & $15.86 \%$ & $22.00 \%$ \\
\hline Carinthia & $5.73 \%$ & $1.38 \%$ & $4.00 \%$ \\
\hline Tyrol & $10.47 \%$ & $3.45 \%$ & $6.00 \%$ \\
\hline Upper Austria & $16.45 \%$ & $21.38 \%$ & $18.00 \%$ \\
\hline Salzburg & $7.72 \%$ & $5.52 \%$ & $6.00 \%$ \\
\hline Vorarlberg & $5.58 \%$ & $4.14 \%$ & $2.00 \%$ \\
\hline Sample size & 55,566 & 145 & 50 \\
\hline
\end{tabular}

Notes. The displayed shares refer to arithmetic means. For this reason, the sums of shares add up to $>100 \%$ in cases where companies report more than one major industry; NACE codes: A: agriculture, forestry and fishing; B: mining and quarrying; C: manufacturing, D: electricity, gas, steam and air conditioning supply; E: water supply; sewerage, waste management and remediation activities; F: construction; G: wholesale and retail trade; repair of motor vehicles and motorcycles; $\mathrm{H}$ : transportation and storage, I: Accommodation and food service activities; J: information and communication; K: financial and insurance activities; L: real estate activities; M: professional, scientific and technical activities; $\mathrm{N}$ : administrative and support service activities. 


\section{Appendix B}

Propensity score matching results

\begin{tabular}{|c|c|c|c|c|}
\hline & $\begin{array}{l}\mathrm{RC} \text {, "nearest } \\
\text { neighbour" }\end{array}$ & RC, "genetic" & $\begin{array}{l}\mathrm{VC} \text {, "nearest } \\
\text { neighbour" }\end{array}$ & VC, "genetic" \\
\hline Distance & 0.0454 & 0.0353 & 0.0295 & 0.0250 \\
\hline Revenue $\left(€^{`} 000\right)$ & 25,087 & 237,390 & 18,485 & 27,534 \\
\hline Stock market listing ( 1 if yes) & 0.0414 & 0.0667 & 0.0400 & 0.0625 \\
\hline Age since foundation & 16.42 & 18.83 & 14.24 & 14.90 \\
\hline Age since re-organisation & 13.06 & 15.01 & 11.22 & 12.27 \\
\hline Reg. share capital ( $\left(€^{`} 000\right)$ & 5,396 & 15,363 & 2,887 & 10,110 \\
\hline Employees (number) & 79.38 & 75.67 & 50.74 & 75.15 \\
\hline Revenue/employee ( $\left(€^{`} 000\right)$ & 565.5 & 767.3 & 448.7 & 204.6 \\
\hline Companies (number) & 56.72 & 69.58 & 58.92 & 27.46 \\
\hline Shareholders (number) & 5.221 & 6.141 & 13.160 & 9.208 \\
\hline Subsidiaries (number) & 1.407 & 5.948 & 17.600 & 11.271 \\
\hline Creditworthiness ( 1 if yes) & 0.0207 & 0.0000 & 0.0000 & 0.0000 \\
\hline Managers (number) & 2.559 & 2.919 & 2.440 & 2.896 \\
\hline Female managers & 0.0385 & 0.0450 & 0.0643 & 0.0767 \\
\hline Austrian managers only & 0.9248 & 0.9210 & 0.8824 & 0.8987 \\
\hline German managers & 0.0658 & 0.0513 & 0.0620 & 0.0428 \\
\hline Swiss managers & 0.0000 & 0.0006 & 0.0000 & 0.0017 \\
\hline Other foreign mangers & 0.0335 & 0.0197 & 0.0556 & 0.0567 \\
\hline Import quota & 0.1335 & 0.1153 & 0.0630 & 0.0852 \\
\hline Export quota & 0.1798 & 0.1704 & 0.0830 & 0.1348 \\
\hline Foreign shareholders ( 1 if yes) & 0.6759 & 0.6448 & 0.7400 & 0.7083 \\
\hline $\mathrm{R} \& \mathrm{D}$ share & 0.0867 & 0.0645 & 0.0976 & 0.0943 \\
\hline Industry A & $0.00 \%$ & $0.74 \%$ & $0.00 \%$ & $2.08 \%$ \\
\hline Industry B & $4.14 \%$ & $1.48 \%$ & $4.00 \%$ & $4.17 \%$ \\
\hline Industry $\mathrm{C}$ & $20.69 \%$ & $20.74 \%$ & $14.00 \%$ & $14.58 \%$ \\
\hline Industry D & $2.07 \%$ & $0.00 \%$ & $2.00 \%$ & $0.00 \%$ \\
\hline Industry E & $1.38 \%$ & $0.00 \%$ & $2.00 \%$ & $0.00 \%$ \\
\hline Industry F & $4.14 \%$ & $2.96 \%$ & $8.00 \%$ & $0.00 \%$ \\
\hline Industry G & $21.38 \%$ & $13.33 \%$ & $14.00 \%$ & $8.33 \%$ \\
\hline Industry $\mathrm{H}$ & $2.07 \%$ & $2.22 \%$ & $2.00 \%$ & $0.00 \%$ \\
\hline Industry I & $4.14 \%$ & $1.48 \%$ & $4.00 \%$ & $4.17 \%$ \\
\hline Industry $\mathrm{J}$ & $9.66 \%$ & $24.44 \%$ & $6.00 \%$ & $41.67 \%$ \\
\hline Industry $\mathrm{K}$ & $4.14 \%$ & $5.93 \%$ & $2.00 \%$ & $4.17 \%$ \\
\hline Industry L & $2.07 \%$ & $4.44 \%$ & $0.00 \%$ & $0.00 \%$ \\
\hline Industry $\mathrm{M}$ & $28.28 \%$ & $20.00 \%$ & $40.00 \%$ & $22.92 \%$ \\
\hline Industry $\mathrm{N}$ & $0.00 \%$ & $3.70 \%$ & $6.00 \%$ & $2.08 \%$ \\
\hline Vienna & $26.21 \%$ & $37.78 \%$ & $32.00 \%$ & $39.58 \%$ \\
\hline Lower Austria & $13.10 \%$ & $12.59 \%$ & $16.00 \%$ & $8.33 \%$ \\
\hline Burgenland & $2.07 \%$ & $0.74 \%$ & $0.00 \%$ & $2.08 \%$ \\
\hline Styria & $13.10 \%$ & $8.89 \%$ & $16.00 \%$ & $4.17 \%$ \\
\hline Carinthia & $3.45 \%$ & $5.19 \%$ & $2.00 \%$ & $4.17 \%$ \\
\hline Tyrol & $11.03 \%$ & $7.41 \%$ & $12.00 \%$ & $8.33 \%$ \\
\hline Upper Austria & $19.31 \%$ & $16.30 \%$ & $6.00 \%$ & $20.83 \%$ \\
\hline Salzburg & $7.59 \%$ & $5.19 \%$ & $6.00 \%$ & $8.33 \%$ \\
\hline Vorarlberg & $3.45 \%$ & $5.93 \%$ & $10.00 \%$ & $4.17 \%$ \\
\hline Sample size & 145 & 135 & 50 & 48 \\
\hline
\end{tabular}

Note. For industry codes see Appendix A.

\section{Copyrights}

Copyright for this article is retained by the author(s), with first publication rights granted to the journal.

This is an open-access article distributed under the terms and conditions of the Creative Commons Attribution license (http://creativecommons.org/licenses/by/4.0/). 